Archived version from NCDOCKS Institutional Repository http://libres.uncg.edu/ir/asu/

\title{
Appalachľan
}

B O O N , N O R T H C A R O L I N A

\section{Enforcement Of Smoke/Tobacco-Free Policies At Public Universities In The US}

\author{
By: Christopher M. Seitz, Zubair Kabir, Birgit A. Greiner, \\ Martin P. Davoren, and Samuel C. McIntyre
}

\begin{abstract}
Objective: In this study, we examined how smoke/tobacco-free campuses are enforced at 4-year public universities in the United States. Methods: During September of 2016, smoke-free and tobacco-free policies of 4year, public universities were located via the American Nonsmokers' Rights Foundation and the College Navigator websites. Policies were categorized based upon those who were responsible for initially confronting policy violators, those who were responsible for receiving reports of policy violations, methods for reporting a violation, and the types of sanctions for violators. Results: Of 167 policies, most (62\%) relied on the entire campus community (students, faculty, staff) to provide initial policy enforcement. The majority (59\%) did not mention who would receive violation reports, only $15 \%$ included a detailed method for reporting a violation, and over one-third did not mention any sanctions for students, employees, or visitors. Conclusion: This study highlights the need for more specific and robust policy enforcement at smoke/tobacco-free universities.
\end{abstract}

Christopher M. Seitz, Zubair Kabir, Birgit A. Greiner, Martin P. Davoren, Samuel C. McIntyre (2018). Enforcement of Smoke/Tobacco-free Policies at Public Universities in the US. Tobacco Regulatory Science, Volume 4, Number 4, July 2018, pp. 22-31(10). Tobacco Regulatory Science Group. Publisher version of record available at: https://doi.org/10.18001/TRS.4.4.3 


\title{
Enforcement of Smoke/Tobacco-free Policies at Public Universities in the US
}

\author{
Christopher M. Seitz, DrPH, MPH \\ Zubair Kabir, PhD \\ Birgit A. Greiner, PhD \\ Martin P. Davoren, PhD \\ Samuel C. McIntyre, BS
}

Objective: In this study, we examined how smoke/tobacco-free campuses are enforced at 4-year public universities in the United States. Methods: During September of 2016, smoke-free and tobacco-free policies of 4-year, public universities were located via the American Nonsmokers' Rights Foundation and the College Navigator websites. Policies were categorized based upon those who were responsible for initially confronting policy violators, those who were responsible for receiving reports of policy violations, methods for reporting a violation, and the types of sanctions for violators. Results: Of 167 policies, most (62\%) relied on the entire campus community (students, faculty, staff) to provide initial policy enforcement. The majority $(59 \%)$ did not mention who would receive violation reports, only $15 \%$ included a detailed method for reporting a violation, and over one-third did not mention any sanctions for students, employees, or visitors. Conclusion: This study highlights the need for more specific and robust policy enforcement at smoke/tobacco-free universities.

Key words: smoking; tobacco; policy; enforce; university

$\mathrm{T}$ The American College Health Association (ACHA) and American Lung Association recommend that universities prohibit indoor and outdoor tobacco use on campus to protect students, faculty, staff, and visitors from the negative health effects of firsthand and secondhand exposure of tobacco. ${ }^{1,2}$ Their recommendations are based on empirical research. There is compelling evidence in the literature regarding the association between tobacco-free universities and a decrease in tobacco use and secondhand smoke among the campus communtiy. ${ }^{3-11}$

During the past decade, there has been a dramatic increase in the number of smoke-free and tobacco-free universities internationally. Smokefree universities prohibit the use of combustible tobacco products, such as conventional cigarettes, anywhere on campus. Tobacco-free universities, in addition, prohibit the use of non-combustible tobacco product, such as chewing tobacco and ecigarettes anywhere on campus. The Americans for Nonsmokers' Rights Foundation (ANRF) estimates that in 2010, there were only 446 smoke-free universities in the United States (US). By 2016, however, there were over 1400 smoke-free universities. ${ }^{12}$ During the past few years, peer-reviewed research also has suggested a trend of smoke-free campuses in other countries, including the United Kingdom, ${ }^{7}$ Canada, ${ }^{13}$ Spain, ${ }^{14}$ Lebanon, ${ }^{15}$ Saudi Arabia, ${ }^{16}$ Australia, ${ }^{11,17,18}$ and New Zealand. ${ }^{19}$

Even though the number of smoke-free and tobacco-free universities are increasing, research suggests that students, faculty, and staff who use tobacco are not always compliant. Violation of

Christopher M. Seitz, Assistant Professor, Appalachian State University, Department of Health \& Exercise Science, Boone, NC. Zubair Kabir, Senior Lecturer, University College Cork, School of Public Health, Cork, Ireland. Birgit A. Greiner, Senior Lecturer, University College Cork, School of Public Health, Cork, Ireland. Martin P. Davoren, CEO of the Sexual Health Centre Ltd., Cork, Ireland. Samuel C. McIntyre, Liberty University, Department of Public \& Community Health, Lynchburg, VA.

Correspondence Dr Seitz; seitzcm@appstate.edu 
campus tobacco-free policies have been documented internationally in both qualitative $e^{13,17,20}$ and quantitative $^{21-28}$ research studies. For example, in a US study, researchers observed 529 violations of a tobacco-free campus policy during a 4-week period..$^{24}$ In a separate study from Australia, 50 staff and students observed in violation of a tobacco-free policy were interviewed to better understand why people do not comply with the policy. The reasons included: (1) the intentionality of defying a policy that intrudes on self-governance; (2) the inconvenience of walking off campus to smoke; (3) the physiological craving to smoke; (4) the misunderstanding of campus boundaries; and (5) the ability to violate the policy without being seen or without subjecting others to secondhand smoke. ${ }^{17}$

Several experts blame non-compliance on poor enforcement. Faculty, staff, and students, who are both tobacco users and non-users, have voiced concerns about limited enforcement of tobaccofree campus policies. ${ }^{13,17,19,20,27-31}$ Even university presidents consider enforcement to be a hindrance towards establishing a tobacco-free campus. Specifically, after surveying 405 presidents of 4-year universities, researchers found that $68 \%$ of the presidents considered enforcement decisions (eg, deciding who will enforce the policy, deciding on penalties) to be a major barrier to implementing a tobacco-free policy. ${ }^{32}$

Although the ACHA and other health professionals recommend enforcing campus tobacco-free policies, there is a lack of literature regarding how such policies are enforced, if at all. The ACHA suggests that universities should "plan, maintain, and support effective and timely implementation, administration, and consistent enforcement of all college/university tobacco-related policies, rules, regulations, and practices. Provide a well-publicized reporting system for violations." ${ }^{33}$ Health professionals have echoed the ACHA's recommendation; ${ }^{29,34}$ however, only one study, conducted by Plaspohl et $\mathrm{al},{ }^{35}$ has assessed the number of universities that enforce their tobacco-free policy, finding that a majority $(75 \%)$ do so. Unfortunately, the study did not specify the methods of enforcement.

Currently, only 4 studies have evaluated certain approaches to enforcement of smoke/tobacco-free campuses. One study evaluated the impact of handing out educational cards to the campus commu- nity that contained information about the policy and cessation resources. ${ }^{22}$ Three studies evaluated ambassador programs, in which volunteer faculty, staff, and students regularly patrol the campus to inform violators of the policy and politely ask for compliance. ${ }^{24,36,37}$ There was support for the effectiveness of each enforcement program, measured as a decline in collected cigarette butts ${ }^{22,24,36}$ and observed violators post-implementation compared to pre-implementation. ${ }^{24,36}$ This raises the question: Are educational cards and ambassador programs the only ways that universities ensure that people are not using tobacco on campus?

Therefore, the purpose of the study was to address the gap in the literature regarding the "who" and "how" of the issue. Who exactly enforces a smoke-free or tobacco-free campus and how do they do it? Specifically, the study aimed to answer the following research questions: Who is responsible for initially confronting violators and reporting the violation? Who is responsible for receiving violation reports? How are violations reported? How are people sanctioned for violating the policy?

\section{METHODS}

Institutional Review Board review preceded conducting the study. Data were collected from available online websites and did not involve contact with people.

The ANRF maintains a list of colleges that have comprehensive smoke-free or tobacco-free policies. ${ }^{12}$ During September of 2016, we filtered the list to only include 4-year, public universities. Motst $(77 \%)$ of the 17.5 million college students in the US attend public universities versus private universities, and most (58\%) attend 4-year universities as compared to 2-year universities. ${ }^{38}$ As such, we wanted to explore how tobacco control policies are enforced within campus environments that include the largest proportion of university students. In addition, Plaspohl et al's previous research suggests that universities with larger enrollment tend to have weaker enforcement of tobacco-free policies as compared to universities with smaller enrollment. ${ }^{35}$

To determine which universities from the ANRF list were 4-year, public universities, we used the government's National Center for Education Statistics' "College Navigator" website (http://nces. 
ed.gov/collegenavigator/). ${ }^{39}$ College Navigator allows users to filter universities based on demographics of location, public, private, 4-year, and 2-year. Universities that matched both the ANRF list and the College Navigator search were included in the study.

To access the tobacco policies, we followed the hyperlinks included in the ANRF's list. However, if the hyperlink was broken or did not lead directly to the policy, we attempted to locate the policy by using the search pane of each university's website. We used a combination of the following terms: smoking, smoke, tobacco, policy. If the website did not produce the university's tobacco policy, we used the same search terms on the Human Resources' webpage, policy listing webpage, and the most current student and faculty handbooks. In addition to official policies, we also included any supplemental information to the policy, such as a campus website dedicated to informing the community about the policy. These websites tended to include "frequently asked questions" about the policy, which may have provided additional information about enforcement that may not have been specified in the official policy. If we were unable to locate the tobacco policy, it was excluded from the study, because it was assumed that if members of a university community could not easily locate a tobacco policy on the Internet, then they might not contact university administration to determine the official campus tobacco policy.

Policies were categorized based upon those who were responsible for initially confronting policy violators, including: None Mentioned (no one specifically stated for being responsible), Community (every member of the campus community including faculty, staff, and students), Supervisors (administration and/or supervisors of each building or department), Campus Safety (police and/or other campus security staff), Faculty/staff, and Ambassadors (volunteer faculty, staff, and students who regularly patrol the campus to inform violators of the policy).

Policies were also analyzed for those who were responsible for receiving reports of policy violations, which included: None Mentioned (no one specifically stated to receive violation reports), Appropriate Office (an appropriate office receives the report depending on the violator; student violators are reported to Student Affairs or Dean of Students; employee violators are reported to their supervisor or Human Resources; campus visitors are reported to campus police/safety), and Campus Safety (campus police or campus safety receive violation reports). In addition, policies were analyzed to determine if a detailed method (eg, e-mail address, phone number, website) for reporting a violation was listed in the policy.

Finally, policies were also categorized based upon sanctions for violators who were students, employees (faculty and staff), and campus visitors. Table 1 lists the types of sanctions and their descriptions.

\section{RESULTS}

Of the 707 4-year, public universities listed on College Navigator, 169 (24\%) were completely smoke-free or tobacco-free, as determined by the ANRF in 2016. Of these, 2 universities were excluded from the study because we were unable to locate their policies from their websites. This resulted in 167 universities for the final study sample. The universities were located in each region (eg, Northeast, Midwest, South, West) of the US.

\section{Enforcement Responsibility}

Of the sample, $44(26 \%)$ did not mention the persons responsible for initially enforcing the policy to a violator. The most common (62\%) persons responsible for initial enforcement was the entire campus Community, including students, faculty, and staff. From the remaining policies, those responsible for initial enforcement included: a combination of the Community and Campus Safety $(\mathrm{N}=7,4 \%)$, Supervisors $(\mathrm{N}=4,2 \%)$, Campus Safety $(\mathrm{N}=3,2 \%)$, Faculty/staff $(\mathrm{N}=2,1 \%)$, a combination of the Community and Supervisors $(\mathrm{N}=2,1 \%)$, and a combination of the Community and Ambassadors $(\mathrm{N}=2,1 \%)$.

\section{Reporting Violations}

Of the policies, 99 (59\%) did not mention who would receive violation reports. Of the remaining policies, $35(21 \%)$ stated that an "Appropriate Office" would field reports of policy violation, depending on the status of the violator. For example, student violators were typically reported to Student Affairs or the Dean of Students, and employee vio- 
Table 1

Type and Frequency of Sanctions Described in Policies for Violations among Students, Employees, and Visitors

\begin{tabular}{|c|c|c|c|c|}
\hline \multirow[t]{2}{*}{ Type of Sanction } & \multirow[t]{2}{*}{ Description } & \multicolumn{3}{|c|}{ Frequency $(\%)$} \\
\hline & & Student & Employee & Visitor \\
\hline Disciplinary Action & $\begin{array}{l}\text { Violators go through the established disciplinary procedures } \\
\text { of the university, which may be defined through the student } \\
\text { honor code or faculty/staff handbook }\end{array}$ & $84(50 \%)$ & $89(53 \%)$ & $20(12 \%)$ \\
\hline None Mentioned & No sanction stated for policy violation & $60(36 \%)$ & $57(34 \%)$ & $90(54 \%)$ \\
\hline Referral & $\begin{array}{l}\text { Violators referred to the appropriate office, such as Student } \\
\text { Affairs, Human Resources, or Campus Safety }\end{array}$ & $34(20 \%)$ & $37(22 \%)$ & $6(4 \%)$ \\
\hline Fine & Violators must pay a certain monetary fine & $34(20 \%)$ & $29(17 \%)$ & $16(10 \%)$ \\
\hline Verbal Warning & Violators are warned verbally to comply with the policy & $18(11 \%)$ & $16(10 \%)$ & $9(5 \%)$ \\
\hline Written Warning & $\begin{array}{l}\text { Violators are warned through a written document to comply } \\
\text { with the policy }\end{array}$ & $12(7 \%)$ & $11(7 \%)$ & $3(2 \%)$ \\
\hline Court Citation & Violators are cited to stand before a court & $8(5 \%)$ & $8(5 \%)$ & $6(4 \%)$ \\
\hline Dismissal & Violators are fired from their job or expelled as a student & $7(4 \%)$ & $13(8 \%)$ & $0(0 \%)$ \\
\hline Suspension & Violators are suspended from campus for a period of time & $7(4 \%)$ & $6(4 \%)$ & $0(0 \%)$ \\
\hline Educational Meeting & $\begin{array}{l}\text { Violators meet with appropriate office to be educated about } \\
\text { the policy }\end{array}$ & $5(3 \%)$ & $3(2 \%)$ & $0(0 \%)$ \\
\hline Educational Class & $\begin{array}{l}\text { Violators must attend educational and/or cessation classes } \\
\text { about tobacco use, policies, and/or cessation }\end{array}$ & $4(2 \%)$ & $3(2 \%)$ & $0(0 \%)$ \\
\hline Probation & Violators are placed on a probationary period & $4(2 \%)$ & $1(<1 \%)$ & $0(0 \%)$ \\
\hline Community Service & Violators perform acts of service to the community & $3(2 \%)$ & $1(<1 \%)$ & $0(0 \%)$ \\
\hline Homework Assignment & $\begin{array}{l}\text { Violators must complete an educational assignment about } \\
\text { the harms of smoking }\end{array}$ & $2(1 \%)$ & $0(0 \%)$ & $0(0 \%)$ \\
\hline Counseling Session & Violators must attend a session with a counselor & $1(<1 \%)$ & $0(0 \%)$ & $0(0 \%)$ \\
\hline Leave & Violators are told to leave the campus & $1(<1 \%)$ & $1(<1 \%)$ & $43(26 \%)$ \\
\hline Written Reprimand & Violators receive a formal written reprimand & $0(0 \%)$ & $2(1 \%)$ & $0(0 \%)$ \\
\hline Banishment & Violators are permanently banned from campus & $0(0 \%)$ & $0(0 \%)$ & $7(4 \%)$ \\
\hline Arrest & Violators may be subject to criminal arrest from police & $0(0 \%)$ & $0(0 \%)$ & $5(3 \%)$ \\
\hline
\end{tabular}

lators were commonly reported to their supervisor or Human Resources. There were also 22 (13\%) policies that stated Campus Safety would receive violation reports and $11(7 \%)$ policies placed both Appropriate Office and Campus Safety in charge of receiving violation reports.

A total of 25 policies $(15 \%)$ included a detailed method for reporting a violation. Of these, 15 listed a phone number and/or e-mail of either an Appropriate Office or Campus Safety, and 10 provided a Web-based form that allowed members of the campus community to report violations. Half of the Web-based forms were anonymous. Common items on the forms included the location, date, and time of the observed violation, number of violators, status of violators (eg, faculty, staff, student, visitor), names of violators, and an open description of the violation that took place.

\section{Sanctions}

More than one-third of policies (36\%) did not mention any sanctions for students; in addition, policies did not mention sanctions for employees $(34 \%)$ or visitors $(54 \%)$. However, of the policies that did include this information, the most common sanctions for students and employees included Disciplinary Action, Referral, Fine, Verbal Warning, and Written Warning. For visitors, the most common sanctions included Leave, Disciplinary Action, and Fine (Table 1). 


\begin{tabular}{|c|c|c|c|c|c|c|}
\hline \multicolumn{7}{|c|}{$\begin{array}{c}\text { Table } 2 \\
\text { Description of Universities' Progressive Enforcement of Policy Violations }\end{array}$} \\
\hline University & $1^{\text {st }}$ Violation & $2^{\text {nd }}$ Violation & $3^{\text {rd }}$ Violation & $4^{\text {th }}$ Violation & $5^{\text {th }}$ Violation & $6^{\text {th }}$ Violation \\
\hline $\begin{array}{l}\text { Arkansas State } \\
\text { University }\end{array}$ & $\begin{array}{l}\text { Written warning } \\
\text { by campus police; } \\
\text { Report sent to } \\
\text { Student Affairs or } \\
\text { supervisor }\end{array}$ & $\begin{array}{l}\text { Citation to appear } \\
\text { in District Court; } \\
\text { Report sent to } \\
\text { Student Affairs or } \\
\text { supervisor }\end{array}$ & NA & NA & NA & NA \\
\hline $\begin{array}{l}\text { Arkansas Tech } \\
\text { University }\end{array}$ & $\begin{array}{l}\text { Written warning } \\
\text { to students, } \\
\text { employees, and } \\
\text { visitors }\end{array}$ & $\begin{array}{l}\text { Six months } \\
\text { probation for } \\
\text { student; Written } \\
\text { reprimand placed } \\
\text { in folder for } \\
\text { employee; } \\
\text { Visitor banned } \\
\text { from campus }\end{array}$ & $\begin{array}{l}\$ 50 \text { fine for } \\
\text { student and em- } \\
\text { ployees }\end{array}$ & NA & NA & NA \\
\hline $\begin{array}{l}\text { Chicago State } \\
\text { University }\end{array}$ & $\begin{array}{l}\text { Warning by } \\
\text { campus police } \\
\text { to students and } \\
\text { employees }\end{array}$ & $\begin{array}{c}\text { \$25 fine for } \\
\text { students and em- } \\
\text { plyoyees }\end{array}$ & $\begin{array}{l}\$ 50 \text { fine for } \\
\text { student and em- } \\
\text { ployees }\end{array}$ & $\begin{array}{l}\text { Discipline } \\
\text { handled } \\
\text { by Judicial } \\
\text { Affairs for } \\
\text { students and } \\
\text { Human Re- } \\
\text { sources for } \\
\text { employees }\end{array}$ & NA & NA \\
\hline Lander University & $\begin{array}{l}\text { \$15 fine for stu- } \\
\text { dents and } \\
\text { employees }\end{array}$ & $\begin{array}{l}\text { \$20 fine for stu- } \\
\text { dents and employ- } \\
\text { ees; Mandatory } \\
\text { counseloing } \\
\text { session for stu- } \\
\text { dent; Reminder of } \\
\text { assstance program } \\
\text { for employee }\end{array}$ & $\begin{array}{l}\text { \$25 fine for } \\
\text { students and em- } \\
\text { ployees; Manda- } \\
\text { tory counseloing } \\
\text { session for stu- } \\
\text { dent; Reminder of } \\
\text { assstance program } \\
\text { for employee }\end{array}$ & $\begin{array}{l}\text { Student } \\
\text { must stand } \\
\text { before } \\
\text { Judicial } \\
\text { Committee; } \\
\text { Employee } \\
\text { begins } \\
\text { discipline } \\
\text { process }\end{array}$ & NA & NA \\
\hline Lincoln Univesity & $\begin{array}{l}\text { Educational } \\
\text { meeting with } \\
\text { student or } \\
\text { employee about } \\
\text { healthy decisions } \\
\text { regarding smoking }\end{array}$ & $\begin{array}{l}\text { Verbal and written } \\
\text { warning for em- } \\
\text { ployee; Research } \\
\text { assignment and } \\
\text { mandatory training } \\
\text { on tobacco harms } \\
\text { for student }\end{array}$ & $\begin{array}{c}\text { \$50 fine for } \\
\text { student and em- } \\
\text { ployee }\end{array}$ & NA & NA & NA \\
\hline $\begin{array}{l}\text { Louisiana State } \\
\text { University at } \\
\text { Alexandria }\end{array}$ & $\begin{array}{l}\text { Verbal warning } \\
\text { to students, } \\
\text { employees, and } \\
\text { visitors }\end{array}$ & $\begin{array}{l}\$ 10 \text { fine to stu- } \\
\text { dents and employ- } \\
\text { ees (and increase } \\
\text { of } \$ 10 \text { increments } \\
\text { with each subse- } \\
\text { quent violation); } \\
\text { Visitors asked to } \\
\text { leave campus }\end{array}$ & NA & NA & NA & NA \\
\hline & & & & & (continu & n next page) \\
\hline
\end{tabular}

Regarding fines, there were 11 policies for students, 9 policies for employees, and 5 policies for visitors that simply mentioned the possibility of receiving a fine in general, without listing the exact fine amount. However, there were 23 policies for students, 20 policies for employees, and 11 policies for visitors that described the exact amount of the fines, all ranging from $\$ 10$ to $\$ 500$, with a median fine of $\$ 50$.

Finally, there were 14 policies that included a progressive method of sanctioning (Table 2). These policies progressed in sanction intensity with each 
Table 2 (continued)

Description of Universities' Progressive Enforcement of Policy Violations

\begin{tabular}{|c|c|c|c|c|c|c|}
\hline University & $1^{\text {st }}$ Violation & $2^{\text {nd }}$ Violation & $3^{\text {rd }}$ Violation & $4^{\text {th }}$ Violation & $5^{\text {th }}$ Violation & $6^{\text {th }}$ Violation \\
\hline $\begin{array}{l}\text { Mayville State } \\
\text { University }\end{array}$ & $\begin{array}{l}\text { Student is } \\
\text { rerequired to } \\
\text { meet with the } \\
\text { administrator after } \\
\text { course completion }\end{array}$ & $\begin{array}{l}\text { Student receives a } \\
\text { written reprimand } \\
\text { and } \$ 100 \text { fine }\end{array}$ & $\begin{array}{l}\text { Student receives } \\
\text { further discipla- } \\
\text { nary action, which } \\
\text { may include fines, } \\
\text { probation, and } \\
\text { suspension }\end{array}$ & NA & NA & NA \\
\hline $\begin{array}{l}\text { Southern } \\
\text { University at } \\
\text { New Orleans }\end{array}$ & $\begin{array}{l}\text { Verbal warning } \\
\text { to students and } \\
\text { employees }\end{array}$ & $\begin{array}{l}\text { Disciplinary pro- } \\
\text { bation for student; } \\
\text { Written warning } \\
\text { for employee }\end{array}$ & $\begin{array}{l}\text { Potential dis- } \\
\text { missal for student } \\
\text { and employee }\end{array}$ & NA & NA & NA \\
\hline $\begin{array}{l}\text { University of } \\
\text { Illinois at } \\
\text { Chicago }\end{array}$ & Warning & Final warning & $\begin{array}{l}\$ 50 \text { fine (waived } \\
\text { after completion } \\
\text { of educational } \\
\text { course) }\end{array}$ & $\$ 50$ fine & $\$ 75$ fine & $\$ 100$ fine \\
\hline $\begin{array}{l}\text { University of } \\
\text { Illinois at Urbana- } \\
\text { Champaign }\end{array}$ & Written warning & $\begin{array}{l}\$ 25 \text { fine (waived } \\
\text { after completion } \\
\text { of video educa- } \\
\text { tional program) }\end{array}$ & $\$ 50$ fine & $\$ 100$ fine & NA & NA \\
\hline $\begin{array}{l}\text { University of } \\
\text { Maine at Augusta }\end{array}$ & Warning to student & Warning to student & $\begin{array}{l}\$ 25 \text { fine or } 2 \\
\text { hours community } \\
\text { service for student }\end{array}$ & $\begin{array}{l}\$ 50 \text { fine } \\
\text { or } 4 \text { hours } \\
\text { community } \\
\text { service for } \\
\text { student }\end{array}$ & $\begin{array}{l}\text { Disciplin- } \\
\text { ary action, } \\
\text { including } \\
\text { possible } \\
\text { suspension } \\
\text { of student }\end{array}$ & NA \\
\hline $\begin{array}{l}\text { University of } \\
\text { Massachusets } \\
\text { Amherst }\end{array}$ & $\begin{array}{l}\text { Educational meet- } \\
\text { ing with employee }\end{array}$ & $\begin{array}{l}\text { Written warning to } \\
\text { employee }\end{array}$ & $\begin{array}{l}\text { One day suspen- } \\
\text { sion of employee }\end{array}$ & $\begin{array}{l}\text { More than } \\
\text { one day sus- } \\
\text { pension of } \\
\text { employee }\end{array}$ & NA & NA \\
\hline $\begin{array}{l}\text { University of } \\
\text { Montana }\end{array}$ & $\begin{array}{l}\text { Educational meet- } \\
\text { ing with student } \\
\text { or employee about } \\
\text { the policy }\end{array}$ & $\begin{array}{l}\text { E-mail sent to stu- } \\
\text { dent or employee } \\
\text { about the policy }\end{array}$ & $\begin{array}{c}\text { Task Force makes } \\
\text { recommendations } \\
\text { to administration } \\
\text { on a case-by-base } \\
\text { basis }\end{array}$ & NA & NA & NA \\
\hline $\begin{array}{l}\text { University of } \\
\text { Oklahoma-Health } \\
\text { Sciences Center }\end{array}$ & $\begin{array}{l}\text { Students, employ- } \\
\text { ees, and visitors } \\
\text { given a warning } \\
\text { and reminder of } \\
\text { the policy }\end{array}$ & $\begin{array}{l}\text { Students, employ- } \\
\text { ees, and visitors } \\
\text { given a } \$ 10 \text { fine }\end{array}$ & $\begin{array}{l}\text { Students, employ- } \\
\text { ees, and visitors } \\
\text { given a } \$ 50 \text { fine }\end{array}$ & NA & NA & NA \\
\hline
\end{tabular}

subsequent violation. All of these policies began with a low level of punishment for the first violation (eg, verbal warning, written warning, $\$ 15$ fine) and then progressed in a range of 2 to 5 additional sanctions of increased disciplinary action (eg, mandatory counseling session, probation, suspension, $\$ 25$ fine, $\$ 50$ fine).

\section{DISCUSSION}

This study was timely given the growing popularity of smoke/tobacco-free university policies, the major issue of non-compliance and the lack of literature specifying enforcement strategies for smoke/tobacco-free campuses. Our paper presented the processes used by smoke/tobacco-free universities for confronting violators, reporting/ receiving violations, and sanctioning violators. Although one-third of the universities did not list any sanctions for policy violation, and most placed the responsibility of enforcement on the entire campus community, other universities embraced a variety of sanctions and progressive disciplinary actions. Our findings have practical implications for college 
administration designing a smoke/tobacco-free campus policy. Specifically, the findings can act as a resource for which enforcement methods are currently being used or not used by other colleges.

Most of the policies placed the responsibility of enforcement almost entirely on the community. The literature indicates that, in general, people are not assertive enough to ask a smoker to extinguish a cigarette. ${ }^{40-43}$ Perhaps most telling is that staff at smoke-free hospitals have reported fear of confronting policy violators. ${ }^{44,45}$ If staff at a hospital, whose focus is improving the health and wellbeing of others, will not enforce a smoke-free policy, then expecting all students, faculty, and staff at a university to confront tobacco users may be unrealistic.

Regardless of assertiveness, only 25 policies specifically listed how people could report a violation (eg, phone number, e-mail, Web-based report). Assuming that an entire university community was bold enough to confront a policy violator, how could they report a violation if they do not know who to contact?

Unfortunately, our study found that many of the smoke-free and tobacco-free policies also lacked "teeth" (ie, sanctions). Specifically, one-third or more of the colleges did not list any sanctions for students, employees, or visitors. This raises Fennell's well-cited question: "Should college campuses become tobacco-free without an enforcement plan?" 29 Several studies from the US have indicated that large percentages of students and employees want sanctions, with most preferring warnings/reminders and fines ${ }^{18,28,40,46,47}$ The perceived need for strict campus-based sanctions is also reflected among campuses located in other countries. ${ }^{13,15,16,18,19}$ As such, smoke-free or tobacco-free policies should include a component regarding enforcement with clear sanctions.

It is interesting that educational interventions were not used as a common sanction. Only 9 policies (7\%) included an educational meeting, educational class, or homework assignment. In comparison, it is commonplace in colleges to mandate that student violators of campus alcohol policies complete an educational class on alcohol abuse. ${ }^{48}$ Perhaps universities should view tobacco policy violations as an opportunity to encourage cessation and refer violators to appropriate service or resources, as opposed to merely fining or warning a violator. For instance, a random survey of students and staff at a large university in Australia found that of 969 participants, $32 \%$ reported wanting sanctions that included education for smoking cessation. ${ }^{18}$

It is also worth noting that only 14 universities had a progressive process of sanctioning. Nicotine is addictive. ${ }^{49}$ Research indicates that smokers need to make several quit attempts before succeeding in becoming a non-smoker. ${ }^{50}$ By adopting a progressive style of sanctioning, universities may provide addicted tobacco users with some much-needed opportunity to adapt to a tobacco-free policy.

\section{IMPLICATIONS FOR TOBACCO REGULATION}

There are important implications from our study. First, our findings revealed a wide range of measures used by the universities to ensure compliance with tobacco-free policies; however, there is a need for a more robust scientific evidence base for the best form of enforcement. To our knowledge, only ambassador programs and the handing out of reminder cards for observed violators have been researched in relation to effectiveness, with some evidence of success of increased compliance. 22,24,36,37 There is a need for researchers to make a systematic comparison of the different forms of enforcement and compliance winning strategies including the "soft" approaches (eg, warnings, educational classes) and "hard" approaches (eg, fines, disciplinary action), as well as investigate the benefits of progressive sanctions. In addition, given that tobacco-free campuses are becoming more popular in other parts of the world, and because most of the previous research about compliance/ enforcement was conducted in the US and Canada, additional international research is needed to determine whether barriers for implementation of policies and compliance are similar to universities in North America.

Second, administrators at smoke/tobacco-free colleges should consider updating their policies. It was disheartening that one-third of the policies in the study did not specify any sanctions for violations and that over $60 \%$ of the policies relied on the entire campus community to enforce the policy. These policies can be improved by including new text that is clear and explicit in terms of this study's research questions. We suggest that univer- 
sity administrators consider the following items for policy reform: (1) specify who is responsible for enforcing the policy; (2) place responsibility of enforcement beyond the entire community to include other campus authorities (eg, ambassadors, campus safety); (3) provide contact information (eg, e-mail, phone number) of those responsible for fielding violation reports, or provide other mediums for violation reports (ie, anonymous online portal); and (4) include specific sanctions (eg, soft, hard, progressive, educational) for policy violations.

Third, administrators at smoke/tobacco-free colleges may want to consider a combination of community-based enforcement but without sanctions and rely on change of norms and denormalization of tobacco use over time. Fallin-Bennett et $\mathrm{al}^{51}$ compared the various enforcement strategies of 16 California universities with differing tobacco policies. After interviewing 68 key informants, the researchers suggested using a "carrot and stick" approach, in which all community members enforce the policy by raising social norms of a smoke-free area, as well as relying on campus safety or supervisors for more formal enforcement. They found that due to non-compliance, universities that solely relied on community-based enforcement eventually felt the need to transition to a more formalized enforcement with sanctions.

Finally, enforcement of smoke/tobacco-free policies also should be formed on each university's distinctive non-compliance data. Suppose that non-compliance is not a major issue at a smoke/tobacco-free campus, then it could be assumed that only using community-based enforcement without sanctions would be warranted. For example, Seo et al's ${ }^{10}$ longitudinal analysis found improvements of students' smoking behavior/attitudes before and after a smoke-free policy was implemented. The improvements on campus were documented, even though the policy was not actively enforced. On the other hand, campuses experiencing non-compliance, may want to use enforcement strategies that we recommended previously in this paper. There are many tools in the published literature that can be used to measure compliance and inform enforcement needs. These include questionnaires ${ }^{26}$ observational assessment, ${ }^{21,23,24,52}$ and the mapping of littered cigarette butt "hot spot" areas. ${ }^{24,53}$

\section{Limitations}

There are limitations that need to be considered when interpreting the results of the study. First, we only included 4-year public universities. Enforcement strategies may differ in private universities. Second, although we were able to locate all but 2 of the smoke/tobacco-free policies of the 169 eligible universities, we may have missed recent updates of policies that were not available online. In addition, because all policy information was collected through the Internet, it is possible that policies may have existed or that retrieved policies included enforced elements that were not documented online.

\section{Human Subjects Approval Statement}

The Institutional Review Board (IRB) of Appalachian State University considered the study to be non-human subjects research, and therefore, exempt from full IRB review.

\section{Conflict of Interest Disclosure Statement}

All authors of this article declare they have no conflicts of interest.

\section{References}

1. American College Health Association. Position statement on tobacco on college and university campuses. J Am Coll Health. 2012;60(3):266-267.

2. American Lung Association. Smokefree environments. Available at: http://www.lung.org/our-initiatives/tobacco/smokefree-environments/. Accessed May 3, 2016.

3. Fallin A, Roditis M, Glantz SA. Association of campus tobacco policies with secondhand smoke exposure, intention to smoke on campus, and attitudes about outdoor smoking restrictions. Am J Public Health. 2015;105(6):1098-1100.

4. Figueroa H, Wolfersteig W. Mixed-methods evaluation and cost-effectiveness analysis of a tobacco-free campus initiative. Paper presented at: 142nd APHA Annual Meeting and Exposition; November 15-19, 2014; New Orleans, Louisiana. Available at: https://apha.confex. com/apha/142am/webprogram/Paper304690.html. Accessed May 14, 2018.

5.Lechner WV, Meier E, Miller MB, et al. Changes in smoking prevalence, attitudes, and beliefs over 4 years following a campus-wide anti-tobacco intervention. J Am Coll Health. 2012;60(5):505-511.

6. Lee JG, Ranney LM, Goldstein AO. Cigarette butts near building entrances: what is the impact of smoke-free college campus policies? Tob Control. 2013;22(2):107-112.

7. Lupton JR, Townsend JL. A systematic review and metaanalysis of the acceptability and effectiveness of university smoke-free policies. J Am Coll Health. 2015;63(4):238247. 
8. Mason M, Lust K, Sanem J, et al. Impact of smoke-/ tobacco-free policies on student tobacco-use rates at postsecondary institutions in Minnesota. Paper presented at 142nd APHA Annual Meeting and Exposition; New Orleans, Louisiana; November 15-19, 2014. Available at: https://apha.confex.com/apha/142am/webprogram/ Paper302274.html. Accessed May 14, 2018.

9. Meier E, Lechner WV, Miller MB, et al. Changes in smokeless tobacco use over four years following a campus-wide anti-tobacco intervention. Nicotine Tob Res. 2013;15(8):1382-1387.

10. Seo DC, Macy JT, Torabi MR, et al. The effect of a smokefree campus policy on college students' smoking behaviors and attitudes. Prev Med. 2011;53(4-5):347-352.

11. Burns S, Hart E, Jancey J, et al. A cross sectional evaluation of a total smoking ban at a large Australian university. BMC Res Notes. 2016;9:288.

12. American Nonsmokers' Rights Foundation. Smokefree and tobacco-free U.S. and tribal colleges and universities. Available at: http://no-smoke.org/goingsmokefree. php?id=447. Accessed September 19, 2016.

13. Baillie L, Callaghan D, Smith ML. Canadian campus smoking policies: Investigating the gap between intent and outcome from a student perspective. J Am Coll Health. 2011;59(4):260-265.

14. Duaso MJ, De Irala J, Canga N. Employee's perceived exposure to environmental tobacco smoke, passive smoking risk beliefs and attitudes towards smoking: a case study in a university setting. Health Educ Res. 2006;21(1):26-33.

15. Chaaya M, Alameddine M, Nakkash R, et al. Students' attitude and smoking behaviour following the implementation of a university smoke-free policy: a cross-sectional study. BMJ Open. 2013;3:e002100.

16. Almutairi KM. Attitudes of students and employees towards the implementation of a totally smoke free university campus policy at King Saud University in Saudi Arabia: a cross sectional baseline study on smoking behavior following the implementation of policy. J Community Health. 2014;39(5):894-900.

17. Jancey J, Bowser N, Burns S, et al. No smoking here: examining reasons for noncompliance with a smoke-free policy in a large university. Nicotine Tob Res. 2014;16(7):976983.

18. Burns S, Jancey J, Bowser N, et al. Moving forward: a cross sectional baseline study of staff and student attitudes towards a totally smoke free university campus. $B M C$ Public Health. 2013;13:738.

19. Marsh L, Robertson LA, Cameron C. Attitudes towards smokefree campus policies in New Zealand. $N Z$ Med J. 2014;127(1393):87-98.

20. Strehl E, Harris KJ, Carter L, et al. Limitations and strengths of a university's new tobacco free policy. Paper presented at The University of Montana Graduate Student Research Conference; Missoula, Montana; April 12, 2014. Available at: https://scholarworks.umt.edu/ cgi/viewcontent.cgi?article=1042\&context=gsrc Accessed May 14, 2018.

21. Fallin A, Megan M, Johnson AO, et al. Measuring compliance with tobacco-free campus policy. J Am Coll Health. 2012;60(7):496-504.

22. Fallin A, Johnson AO, Riker C, et al. An intervention to increase compliance with a tobacco free university policy.
Am J Health Promot. 2013;27(3):162-169.

23. Ickes M, Gokun Y, Rayens MK, et al. Comparing two observational measures to evaluate compliance with tobaccofree campus policy. Health Promot Pract. 2015;16(2):210217.

24. Ickes MJ, Hahn EJ, McCann M, et al. Tobacco-free Take Action!: increasing policy adherence on a college campus. World Med Health Policy. 2013;5(1):47-56.

25. Mamudu HM, Veeranki SP, He Y, et al. University personnel's attitudes and behaviors toward the first tobacco-free campus policy in Tennessee. J Commun Health. 2012;37(4):855-864.

26. Mamudu HM, Veeranki SP, Kioko DM, et al. Exploring support for $100 \%$ college tobacco-free policies and tobacco-free campuses among college tobacco users. I Public Health Manag Pract. 2016;22(1):29-39.

27. Record RA. Increasing compliance with a tobacco-free policy via a campus campaign. [dissertation]. Lexington, KY. University of Kentucky; 2014. Available at: https:// uknowledge.uky.edu/comm_etds/30/. Accessed May 14, 2018.

28. Russette HC, Harris KJ, Schuldberg D, et al. Policy compliance of smokers on a tobacco-free university campus. $J$ Am Coll Health. 2014;62(2):110-116.

29. Fennell R. Should college campuses become tobacco free without an enforcement plan? J Am Coll Health. 2012;60(7):491-494.

30. Medeiros E. Attitudes, perceptions, and support of student leaders for a tobacco-free campus policy at the University of Washington: a pilot qualitative study. [master's thesis]. Seattle, WA. University of Washington; 2016. Available at: https://digital.lib.washington.edu/researchworks/handle/1773/36717. Accessed May 14, 2018.

31. Fallin A, Roditis M, Glantz SA. Enforcement of college campus tobacco-free policies. Paper presented at: $143 \mathrm{nd}$ APHA Annual Meeting and Exposition; October 31-November 4, 2015; Chicago, IL. Available at: https://apha. confex.com/apha/143am/webprogram/Paper328171. html. Accessed on May 14, 2018.

32. Reindl D, Glassman T, Price J, et al. Perceptions of college and university presidents regarding tobacco-free campus policies. J Am Coll Health. 2014; 62(3):193-202.

33. American College Health Association. Position statement on tobacco on college and university campuses. J Am Coll Health. 2012;60(3):266-267.

34. Glassman TJ, Reindl DM, Whewell AT. Strategies for implementing a tobacco-free campus policy. J Am Coll Health. 2011;59(8):764-768.

35. Plaspohl SS, Parrillo AV, Vogel R, et al. An assessment of America's tobacco-free colleges and universities. J Am Coll Health. 2012;60(2):162-167.

36. Ickes MJ, Rayens MK, Wiggins AT, et al. A tobacco-free campus ambassador program and policy compliance. $J$ Am Coll Health. 2015;63(2):126-133.

37. Kuntz M, Seitz CM, Nelson M. Enforcing a tobacco-free campus through an ambassador-based program: a phenomenology. J Am Coll Health. 2015;63(3):195-202.

38. National Center for Education Statistics. Digest of Education Statistics. Available at: http://nces.ed.gov/programs/digest/d15/tables/dt15_105.20.asp?current=yes. Accessed September 27, 2016.

39. National Center for Education Statistics. College Navi- 
gator. Available at: http://nces.ed.gov/collegenavigator/. Accessed September 20, 2016.

40. Figueroa HL, Totura CMW, Brien S, et al. Evaluation of Arizona State University's tobacco-free campus policy: assessment of policy impacts and return on investment. Available at: https://eoss.asu.edu/sites/default/files/Tobacco\%20Free\%20Campus\%202014\%20Final\%20Report\%207-2-14.pdf. Accessed September 28, 2016.

41. Niles N, Barbour, K. Student attitudes towards a tobacco free campus policy. Acad Health Care Manage J. 2011;7(1):53-68.

42. Germain D, Wakefield M, Durkin S. Non-smokers' responses when smokers light up: a population-based study. Prev Med. 2007;45(1):21-25.

43. Poland BD, Cohen JE, Ashley MJ, et al. Heterogeneity among smokers and non-smokers in attitudes and behaviour regarding smoking and smoking restrictions. Tob Control. 2000;9(4):364-371.

44. Shipley M, Allcock R. Achieving a smoke-free hospital: reported enforcement of smoke-free regulations by NHS health care staff. J Public Health. 2008;30(1):2-7.

45. Ratschen E, Britton J, McNeill A. Smoke-free hospitals the English experience: results from a survey, interviews, and site visits. BMC Health Serv Res. 2008,8:41.

46. Britt JD. To be or not to be smoke-free: an analysis of the University of Alaska Anchorage peer institutions' smoking and tobacco policies. [master's thesis]. Anchorage, AK. University of Alaska Anchorage; 2014. Available at: https://scholarworks.alaska.edu/handle/11122/4350 Accessed May 14, 2018.

47. Whipple K, Simmons SJ, Caldwell R, et al. Assessing sup- port for campus tobacco policy in tobacco country. The Health Educator. 2010;42(1):3-11.

48. Barnett NP, Read JP. Mandatory alcohol intervention for alcohol-abusing college students: a systematic review. $J$ Subst Abuse Treat. 2005;29(2):147-158.

49. US Department of Health and Human Services. The Health Consequences of Smoking - 50 Years of Progress: A Report of the Surgeon General. Atlanta, GA: US Department of Health and Human Services, US Centers for Disease Control and Prevention, National Center for Chronic Disease Prevention and Health Promotion, Office on Smoking and Health; 2014. Available at: http:// www.surgeongeneral.gov/library/reports/50-years-ofprogress/full-report.pdf Accessed November 17, 2016.

50. Chaiton M, Diemert L, Cohen JE, et al. Estimating the number of quit attempts it takes to quit smoking successfully in a longitudinal cohort of smokers. BMJ Open. 2016;6:e011045.

51. Fallin-Bennett A, Roditis M, Glantz SA. The carrot and the stick? Strategies to improve compliance with college campus tobacco policies. J Am Coll Health. 2017;65(2):122-130.

52. Burke RC, Cinderich AB, Prince L, Curtis A. Utilizing geographic information systems and spatial video to analyze patterns of secondhand smoke exposure on college campuses. J Am Coll Health. 2015;63(8):574-578.

53. Pires SF, Block S, Belance R, Marteache N. The spatial distribution of smoking violations on a no-smoking campus: implications for prevention. J Am Coll Health. 2015;64(1):62-68. 